\title{
Sight lines, sight areas and unbroken open spaces? More-than-representational conceptualisations in Dutch landscape planning
}

\author{
M. Bulkens, C. Minca, and H. Muzaini \\ Cultural Geography Group, Wageningen University, P.O. Box 47, 6700 AA, Wageningen, the Netherlands \\ Correspondence to: C. Minca (claudio.minca@wur.nl)
}

Received: 20 January 2015 - Revised: 14 July 2015 - Accepted: 21 August 2015 - Published: 11 September 2015

\begin{abstract}
Drawing on the case study of the Wageningse Eng, the Netherlands, this paper examines a set of spatial metaphors (and their attendant grounded impacts) employed within two key policy documents - the allocation plan and a related map - pertaining to how the cultural landscape is to be spatially managed and developed by the municipality. Although promoted as being based on historical facts and a cornerstone of Dutch commitment to participatory planning, the case being studied reveals the ways in which these metaphors are at times not only entirely subjective and arbitrary, but also perceived by residents and users as neglecting their rights with respect to the landscape and as instruments constraining what can or cannot be done in that area. More broadly, in the face of calls for more non-representational approaches to landscape analysis, the paper shows the continued salience of representational practices within spatial planning and how these may hold very material implications for landscapes.
\end{abstract}

\section{Introduction}

On 30 July 2012, "De Veluwepost", a local newspaper of Wageningen, a town of about 37000 inhabitants located just north of the river Rhine in the Dutch province of Gelderland (Gemeente Wageningen, 2012c), reports that, by order of the municipality, a walnut tree of $25 \mathrm{~cm}$ in diameter had to be eliminated from the landscape following a neighbour's complain that it was "blocking the view out of her window". The decision to cut the tree was announced by the alderman second in command after the mayor, and responsible for spatial planning in Wageningen - with the claim, according to the newspaper, that "the allocation plan states that the Eng should be open. Trees are just not allowed" (Boer, 2012).

This episode provides a useful and provocative entry point into examining how the Wageningse Eng, a former agricultural area of 595 acres in size, located at the east side of the municipality, has become the subject of controversy over its development plans. The specific "tree incident" in fact coincided with a period in which the municipality was in the process of determining a new plan aimed at defining the legally binding rules for future spatial developments in the whole area, which inevitably raised the question of deciding "what are you going to allow and what are you not going to allow", especially when citizens are given a say and no clear consensus exists over how rules must be formulated. The complication here arises from the fact that several (former) associations and foundations play a key role in this public debate over local spatial planning, some of which in formal cooperation with the municipality. Drawing on the analysis of two texts that have been most influential in determining how the Wageningse Eng is to be developed and which have provoked much controversy - the still-to-be-determined allocation plan (Gemeente Wageningen, 2012b, 2013) and a map of "sight areas, sight lines and perspectives" produced by the TAWE (Territorial Advisory Committee Wageningse Eng, 2012) - the paper specifically analyses some key geographical metaphors that have been employed in local spatial planning, their effects on the landscape in question, and how residents have ambivalently responded to them. In doing so, it provides an in-depth case study of landscape governance and hegemonic spatial planning practices (with real impacts, such as in the cutting down of the walnut tree) in the (albeit localised) Dutch context, and how these may be contested 
by groups or individuals with vested interests on the ground. More broadly, it takes inspiration from Lorimer's more-thanrepresentational approach (2005) in terms of reflecting upon the continued salience of representational practices and their attendant consequences within society (see, among others, Anderson and Harrison, 2010). Indeed, even as scholars have criticised the "deadening" effect of representational practices (Lorimer, 2005) this paper argues that, at least in Wageningen and possibly in the Dutch context at large, "representational practices" remain key in how power is manifested through particular ideas about and conceptualisations of the landscape.

Following a brief review of recent theoretical shifts within cultural geography, we shed some light on specific features of participatory spatial planning in the Netherlands. This is dovetailed by a description of the case study area and of the methods adopted in the research, alongside introducing the spatial allocation plan for the environs of Wageningen and the above mentioned map produced by the TAWE. Particular emphasis is placed on how spatial/geographical metaphors such as "open fields and spectacular views"; sight lines; and, to a lesser extent, sight areas and perspectives - have been utilised towards justifying specific practices within the Wageningse Eng. Drawing upon a series of in-depth interviews, the paper then demonstrates how these landscape conceptualisations and representations - as maintained by the two key texts here examined - are indeed perceived as "obvious" and "historical" by some, and as "undesirable" and "arbitrary" by others. Based on the findings, the conclusion first stresses how representations still matter a great deal in the crafting not only of ideas about the related landscapes, but also of the material geographies and the spatial practices those ideas may produce when mobilised to become part of a development plan for specific areas. Secondly, it highlights the ways in which, despite well-established discourses presenting Dutch spatial planning as a fundamentally democratic process involving long and extenuating negotiations among the residents and the decision makers (Evers, 2008; Needham, 2007; Hagens, 2010), public debates about the nature and the management of landscapes, in Wageningen, and presumably elsewhere in the Netherlands, are undermined by the workings of specific representations of landscapes delivered by "top-down documents". In Wageningen, despite being the result of widely recognised (and formalised) participatory processes, plans are importantly influenced by a specific set of landscape ideologies and by their related morethan-representational "power", which impact on the real and imagined spatialities of the Wageningse Eng.

\section{Towards a "more-than-representational"} conceptualisation of landscape

As a concept, "landscape" has become the indelible "lens" for many cultural geographers trying to make sense of the interactions between individuals and their environment (Wylie,
2007; see also Minca, 2007a). Following the "cultural turn" of the late 1980s, under the umbrella of what was referred to as "new cultural geography", the main focus has been on the analysis of (elements of) landscapes not only as physical manifestations in the world but also as being highly symbolic and profoundly ideological in terms of the meanings imputed within, or projected through, them (Cosgrove and Jackson, 1987; Duncan and Ley, 1993; Mitchell, 2000, 2001, 2002; Cosgrove and Daniels, 1988; Cresswell and Verstraete, 2003; Minca, 2007b). Far from being reified and necessarily accepted, however, these meanings are often contested by others with different ideas of how landscapes should look and what they should represent: a defining framework adopted by many scholars interested in studying the representational politics of landscapes (Wylie, 2005, 2007; Minca, 2007b). Yet such an approach has subsequently also been critiqued as neglecting the natural, material and embodied aspects of landscapes, and how these affectively and emotionally relate to people. Drawing on the Heideggerian concept of "dwelling", which refers to an active engagement with the material world as "a meaningful place for people through being lived in", anthropologist Ingold (2000:168) highlights how cultural geographers have over-emphasised the representational facets of landscapes (what they mean or what they represent) at the expense of considering the materiality of landscapes and how individuals immanently "engage" with these and are consequently impacted upon by them (see also McHugh, 2009).

Similarly, Thrift has claimed (1996, 2007), through his highly influential non-representational approach, that the new cultural geography has somehow "drained life out" of what was being studied, further echoed more recently by Cadman (2009:1) in terms of the tendency within cultural geography "to retreat from practice into the (cultural) politics of representation, creating deadening effects in an otherwise active world". Such deadening effects, according again to Thrift (1996), may however be counteracted by turning away from the idea that landscapes are a sort of "end product of social and spatial processes" towards considering them as "practices" in and of themselves. This is what Lorimer (2005:85) refers to as the "embodied acts of landscaping" or the ways in which we actively and materially shape and engage with the landscapes, of which we are a constitutive part. Within this approach, it is the interactions between people and their use of - and relationships to - their everyday environments that constitute more of a landscape, rather than just the meanings underlying them. Oakes and Price (2008:151) liken this to seeing landscapes "as a sort of performance that is enacted as much as is music or theatre". In these terms, the landscape therefore becomes a fluid construct constantly in the process of "becoming", never "fixed", and thus moving away "from a view of the world based on contemplative models of thought and action toward theories of practice which amplify the potential flow of events" (Thrift, 2000:556; also, Lorimer, 2005; Wylie, 2007). In recent years, such an approach has been applied to different landscape-related issues: 
from Crouch's $(2000,2003)$ research on encounters and embodiment in leisure and tourism via the study of caravanning and allotment gardening, to Dewsbury's (2000) and Harrison's (2000) discussion of the relationship between embodiment and space, to Lorimer's writings on learning geography (2003) and herding (2006), as well as to Wylie's (2005) reflections on walking.

One problem with the non-representational approach, however, is that it all too often underplays the fact that, in many spheres of life, landscapes are still viewed and treated "representationally", with a strong emphasis placed on the set of meanings that make them up and/or that they have been engineered to project (Lorimer, 2005). This is especially the case in the context of the work on/in landscape planning and participatory politics (Cadman, 2009). Hillier (2007), for instance, uses the term "post-representational" to argue that planning practices still largely revolve around representations, particularly representations of planning areas captured within visual texts such as plans and maps. She indeed maintains that in "planning practice" these representations are all too often taken for granted as natural, hegemonic and absolute truths of the world out there, "rather than reflecting the multidimensional, often conflicting representations which coexist in reality" (Hillier, 2007:195). She also argues for a much-needed step back to reflect upon the coming about of these representations, upon how these affect planning practices, and how they may be contested. A similar claim is made by Healey, suggesting that the "analysis of the nature of concepts of place and space being deployed" is a less-developed field of planning studies, while these concepts have a performative capacity in shaping the actual spatial developments of areas (2004:46; also 2002). This seems especially relevant when it is recognised that "policymakers and planners [do not] care much about lived schemes of signification" (Plłger, 2006:393).

The present article thus touches upon these debates within cultural geography and spatial planning by exemplifying the still-dominant position of landscape representations (compared to people's everyday landscape practice) in one illustrative case of local Dutch spatial planning, as well as engaging with the complex entanglements of representations and meaning in planning as not only ideological and hegemonic but also polyvocal and contested. Further, to consider the non-representational aspects of landscape (i.e. the practices that constitute it) does not necessarily imply that questions of intended meaning and the resulting (often contested) interpretations become unimportant. In fact, as Dewsbury et al. (2002:438) have argued, we should perceive representations "not [only] as a code to be broken or as an illusion to be dispelled, [but] rather representations [should be] apprehended as performative in themselves; as doings". The focus, therefore, should be on the act of representing itself, an act that does not solely communicate a message which may either be accepted or resisted (hence lending to contestation or negotiation) - but an act capable of chang- ing and transforming individuals and their surroundings. Accordingly, landscapes may therefore be seen as representational not only in terms of what "they mean" but also in terms of what they "do" to people's everyday practice. It is in line with this thinking that Lorimer (2005) introduces the term "more-than-representational", a term that allows landscapes to be understood and studied not only for what they represent but also for how they are performed towards real impacts (see also Anderson and Harrison, 2010). In this regard, landscapes thus become also active agents in themselves and not merely the end product of human actions and cognition, as conceived before under the auspices of new cultural geography.

\section{Methods}

The contemporary political and social climate in the Netherlands has often been described as embracing the values of compromise and consensus building, a philosophy that extends to the ways in which spatial planning is carried out in the entire country today (Evers et al., 2008; Hagens, 2010). Spatial planning scholar Barrie Needham (2007), studying land use planning in the Netherlands, famously traces this back to the "polder model" adopted in Dutch history, when water boards - governmental bodies maintaining the water system and safeguarding water safety - were created before any other form of public administrative body. Given the authority by the citizens to manage and maintain the polders, the water boards applied a deliberative process which mediated the interests of landowners and land users towards finding consensus or, when impossible, an acceptable compromise. This strategy, and "philosophy" behind it, soon spread as a way of managing public life, including that of spatial planning carried out in the entire country. Such an arguably "inclusive" approach, however, is not devoid of problems. For Needham (2007) it may produce "grey compromises" or, even worse, "lowest common denominator solutions", thus making Dutch spatial planning "viscous" and "sticky". Similarly, Habiforum (2003) - an influential network of professionals in spatial planning and area development - describes issues pertaining to the management of conflicts of interest as among the major challenges faced in the past decades by spatial planning in the Netherlands. Even so, as part of broader processes in which citizens and non-governmental organisations are, at the local level, able to participate in decision-making processes (Van Assche, 2004), ideas such as "consultation" and "cooperation" between different groups remain key to the ways in which landscapes in the Netherlands, including the Wageningse Eng, are planned (Needham, 2007:35).

While historically used for grain farming, predominantly rye, in the 18th and 19th century, tobacco became the most grown crop at the Wageningse Eng. (The addition "Eng" refers to arable land at a high and dry location.) In recent 


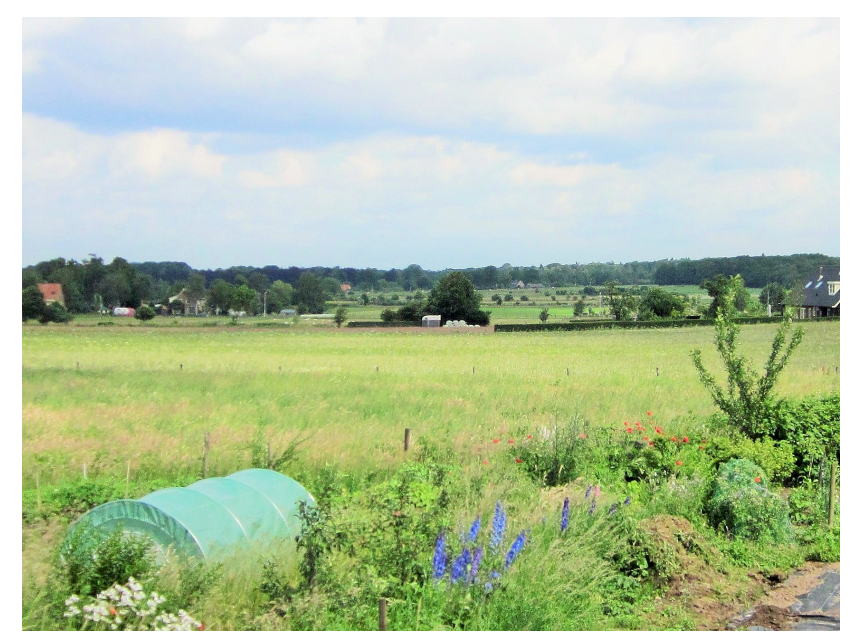

Figure 1. The Wageningse Eng, south side, photo by Maartje Bulkens.

years, however, the actual use of the Eng for agricultural purposes has been rather limited given its unprofitability, resulting in recreational and residential uses becoming more dominant. These include horse keeping, allotment gardening, small-scale biological farming, flower-picking gardens, and the cultivation of trees and plants (see Fig. 1) (Renes, 1993; Gemeente Wageningen, 2012a, b).

To manage such a variety of vested interests in the area, and in favour of public participation in spatial planning, formal organisations have emerged. In 2009, for example, the "Stichting Wageningse Eng" (SWE) was established to

stimulat[e] the maintenance and, where possible, the improvement of the natural landscape and cultural historical values of the Eng, as well as the development and facilitation of new sustainable forms of [land] use at and in favour of the Eng (Stichting Wageningse Eng, 2012; translation by authors).

In order to keep the diverse tasks of the foundation distinct, three subcommittees were created: the executive committee, the advisory committee and the TAWE. The executive committee is responsible for managing the foundation and representing the many different interests in the area. The advisory committee - composed of members with different stakes in the area, including residents, recreational users, users, etc. provides the foundation with solicited and unsolicited advice. Finally, the TAWE was appointed by the mayor and the Aldermen to garner advice on matters pertaining to the granting of licenses, municipal spatial development policy, and any other issues related to the landscape of the Wageningse Eng (Stichting Wageningse Eng, 2012).

Other involved associations are Mooi Wageningen (Beautiful Wageningen), constituted by individuals concerned with the protection and preservation of "irreplaceable values of the surrounding nature and landscape of Wageningen" (Mooi
Wageningen, 2012), and the Vereniging van Gebruikers en Eigenaren van de Wageningse Eng (Association of Owners and Users of the Wageningse Eng, now disbanded), made up predominantly of residents and users of the area who want more opportunities to participate in the spatial development at the Wageningse Eng.

Our fieldwork took place mainly in June 2012 in the weeks immediately following the release, on the part of the municipality of Wageningen, of the "predesign", a provisional design opened to initial public discussion leading to the crafting of the official final design of the allocation plan. During this period, 15 "narrative interviews" (Jovchelovitch and Bauer, 2000), each lasting between 1.5 and $2.5 \mathrm{~h}$, were conducted, in which interviewees were invited to narrate their own impressions of the Wageningse Eng and their views pertaining to the forging of the new allocation plan. Seven of these were with residents of the sparsely populated area, and eight with representatives of organisations that have played important roles in the actual planning processes. To consider the role of the municipality itself, we also interviewed the alderman. While not meant to be generalisable, this sampling has indeed allowed us to capture the diversity of stories related to the process of establishing the new allocation plan, and about spatial planning processes at the Wageningse Eng more generally. Because of the direct involvement of the interviewees in the projects examined here, only pseudonyms are used. These interviews were first coded and mined for relevant themes that emerged, and further supplemented by an analysis of policy documents and publicly available commentaries published during the period, which provided data on "political" processes at the Eng in relation to the allocation plan. Central to these interviews were ideas promoted/presented by the allocation plan and "the map", to which we now turn.

\section{The forthcoming Wageningen allocation plan and TAWE map}

Dutch spatial plans are produced at different levels of government: national, regional/provincial, and local/municipal. However, only the local/municipal allocation plan has direct legal consequences for citizens (see, for example, van der Valk, 2002). As a consequence, any decision to build or change a particular land use requires a permit granted by the municipality, which is evaluated on the basis of the allocation plan. Indeed, the municipality is obliged to grant permits when the applications conform to the current plan. For rural areas the implementation of an allocation plan is compulsory, while for urban areas this is optional (van der Valk, 2002; Needham, 2008).

At the time of our research (Summer 2012), the Wageningen municipality was in the process of determining an upto-date allocation plan. This was a consequence of the 2008 Dutch law on spatial planning requiring that, within the 5 years following the introduction of the new law, all allocation plans would have to be less than 10 years old (deWro, 2013). 
Wageningen met this requirement at the end of September 2013, when the renewed allocation plan was officially decided upon by the municipal council. The new legislation clearly prescribes the procedure to be followed when determining a new allocation plan. Municipalities are obliged to give public notice of these very procedures through the local media, the Staatscourant, and on the Internet. Owners of land parcels included in the area in question must be adequately informed. In the definition of an allocation plan in the Netherlands there are two defining moments of participation for residents. The first is optional and determined in its format by each municipality independently. This takes the form of a predesign. After publishing its predesign, the Wageningen municipality received 55 public comments concerning the future allocation plan, 28 of which about the Wageningse Eng (Gemeente Goes, 2012; Gemeente Wageningen, 2013; deWro, 2013).

The second crucial moment of "public participation" normally takes place after the first draft of the allocation plan has been completed. This is then made public both in print (for example through the local newspapers) and electronically through the national website reporting all legal spatial plans of the Netherlands, a prerequisite so as to allow citizens to express again their views. Municipalities are legally obliged to facilitate this. This is how the Wageningen municipality announced their new plan:

Content-wise there are no major changes in the new allocation plan compared to the current one: the plan is conservative in character. Because of the general standardisation of the plan set-up there may be differences in some of the details. (Staatscourant, 2013; authors' translation).

Citizens can express their views on the document either verbally or in written form, but this must be done within a specific time frame, in order to be able to later lodge an appeal to the determined plan in which a change in allocation or conditions is applied. Within 12 weeks after the end of the period of public consultation, the municipal council digitally determines the allocation plan (deWro, 2013). In the Netherlands, the legal plan is a digital plan and not a hard copy (interview of the alderman of Wageningen municipality, 19 October 2012). The plan consists of three main components: the official design; the accompanying explanation; and the rules describing what is allowed and what is not within particular allocations. It is beyond the scope of this paper to fully examine the rules applied to the Wageningse Eng (see www.ruimtelijkeplannen.nl for the full plan), although, where necessary, references to these will be incorporated in our discussion. For instance, it is perhaps useful to report how the conceptualisation of the Eng is given in the accompanying explanations:

In the past, engen developed at the flanks of the Veluwe. Engen are old agricultural areas characterised by an unbroken open area, surrounded by plants and buildings with small-scale parcelling and cultural historical landscape elements. [...] Due to the differences in height [...] very striking views can be enjoyed in the urban area, the forest area, and the Eng itself. (Gemeente Wageningen, 2012b:26; authors' translation; emphasis added).

In the current allocation plan the area is defined as a "city edge area with special landscape values" [...] One of the basic principles is that of structurally preserving and improving the Eng as a landscape with rich land variations and an open character. The current rights of use will be maintained. Relevant area zoning, with respect to allotment gardens and equestrian sports, are adopted in the allocation plan. [...] New developments are not allowed in the area. (Gemeente Wageningen, 2012b:26; authors' translation; emphasis added)

Within the allocation plan, no further specifications were made with regards to what terms like "unbroken open area" or "striking views" actually meant, although the second key "text" - the sight areas, sight lines and perspectives map, produced by TAWE - attempts to visually capture precisely these. Due to the way in which spatial planning is organised in the area, the map has thus become a specific representation of what both terms entail.

According to the TAWE, a sight area is a broader/vast area over which you can see faraway; $a$ sight line instead denotes a point from which you can gaze at something from a great distance - the example given is that of the windmills near the highway about $10 \mathrm{~km}$ away; finally, a perspective is when you have a view in between two objects, for example a viewpoint in between two lanes of trees. Altogether, the map highlights 17 sight areas, 3 sight lines, and 9 perspectives. On the map, two general subareas are also demarcated: (1) the "open Wageningse Eng" (with sight areas, perspectives and/or sight lines) in the southern part of the Eng, and (2) the "enclosed Eng" or an area with "chambers", which are delineated areas enclosed within pieces of forest or a wooded bank, in the northern part of the Eng (TAWE, 2012). Arguably, although terms like unbroken open area and striking views are not further specified in the allocation plan, they nonetheless emerge in the TAWE's conceptualisations of the Wageningse Eng landscape, the former coinciding with TAWE's visualisation of the "open Eng" and the latter as visualised by TAWE's sight lines and perspectives. However, in contrast to the allocation plan, the TAWE map does not have legal status, and public proposals made during the predesign and design phase for the sight lines to be formalised in the allocation plan were turned down by the municipality for not fitting the conservative character of the plan. It remained unclear during our research why this was so, given how the map did indeed play a key role in the spatial development of the Wageningse Eng. Even so, the map and the specifications of both terms by the TAWE still play an important 
role in the spatial development of the Wageningse Eng, especially in granting permits (TAWE member, personal communication, 13 September 2012). The map has become, in practice, a powerful representation of the Eng landscape due to the TAWE making use of it when advising the municipality. The rest of the paper will thus turn to the different and conflicting ways in which unbroken open area as well as sight lines, sight areas and perspectives are interpreted, despite their prominence in the official documents in characterising (and shaping) the Wageningse Eng landscape. More specifically, we will show how representations and textual conceptualisations of the landscape continue to play an important role in local spatial planning, also in terms of how the material landscape is actually managed and developed.

\section{Results}

\subsection{Dissonant interpretations of unbroken open areas}

According to the predesign of the allocation plan (Gemeente Wageningen, 2012b), an eng is defined as an unbroken open area, which pertains to the idea that the Wageningse Eng has historically been very much an "open" landscape. This view is also echoed by Mr Allen, a member of Mooi Wageningen, although the real extent of this "openness" remains uncertain:

from that history you look at the landscape then it would be nice if in that landscape the historical characteristics remain recognisable, thus that openness is in that sense important. Then you immediately get into discussions about how open it should be, [...] and what kind of sight lines do you need.

This notion of openness is also often mentioned by other respondents when asked to reflect upon the historical development of the Eng. For the alderman,

considering the structure, it has been reasonably open the last period, 25, 40 years, and it has actually always been like that, except for periods when the crops were growing, but that is of course only one part of the year.

The alderman's description here is temporally qualified, referring to how the Wageningse Eng has not always been as open as it is today, since "there was tobacco grown for a while, and then it gradually but surely remained an open area with some small-scale agriculture and cultivation". This indicates how, contrary to what is stated in the allocation plan, the Eng was not always an "open area" despite the fact that, in the last decades, it has become more so.

The conceptualisation of the Eng as an open landscape may perhaps be attributed to a longing for the "museumification" of the landscape, a process in which the landscape is represented as a still frame, to be preserved in its present form, thereby denying the possibility of change, now and in the future, as declared by Mr Hall, former member of the Association of Owners and Users of the Wageningse Eng:

But if one perspective about the Eng becomes dominant, namely the Eng as a beautiful cultural landscape, that should predominantly be maintained, that should remain open [...] the Eng is an area which is used in many different ways by the urban population of Wageningen, let us steer it in the right direction, let us applaud that, and not with a long face of the sight line.

All too often interviewees refer to how the definition of the Eng as an "open landscape" denies many of the current uses of the area. In her public comment to the predesign, the owner of one of the flower-picking gardens makes a plea to gain permission to create new facilities on her terrain, like a shelter; a toilet; a covered wagon; and the possibility of selling coffee, tea and sodas to the general public. She also claims that the TAWE agreed on these plans. However, in the formal response to this request, the municipality states that the TAWE never agreed upon these plans, and that they had to be turned down for not fitting in with the conservative character of an open eng. By representing the Wageningse Eng as an open landscape, therefore, many potential land uses are inhibited.

This could be traced back to the tendency in Dutch landscape planning for the eschewing of elements that may be seen as disturbing the "unity" of the Eng (Coeterier, 1996), such that the new additions were seen as unnecessary disruptions to the overall coherence of the landscape as a visually open space, even as this was never always the case. Here, therefore, a specific set of representations incorporated in the allocation plan have had a deadening effect on the landscape, in line with Healey's (2002:1785) claims that "once an imagination is brought to life, it has material effects", by defining particular restricted practices in/of that landscape, even if there seems to be no historical basis for sustaining such a view. This reflects how dominant representations of a landscape may be questionable in their rendering of the past. As argued by Graham and Healey (1999:641), often planners tend to let the representations of "articulate and powerful groups" become dominant, and may reveal a potentially "performative" capacity where these representations also symbolise "acts" with real impacts on the landscape and its users.

The interpretation of the Eng as an open landscape has also been criticised by other users on the basis of landscape typologies normally adopted in the Netherlands. As Ms Wilkinson, member of the advisory committee avers,

Just take the term open landscape; in Dutch terms this one is not an open landscape, this is a halfopen landscape with carefully chosen boscages, often, at least that is how it should be to protect against the sun, where the agricultural worker could shelter. 
Later she adds that the term also causes problems "because it offers people who want to get rid of boscages and sheds, all opportunity to say it does not fit in an open landscape [sic]". Here again, the idea that, historically, the Eng has never been a totally open landscape emerges. More importantly, however, this quote reflects upon how dominant representations of landscapes within official documents may be skewed in order to achieve particular objectives, in this case to "get rid of boscages and sheds" and prevent alternative spatial developments. Hence, with the representation of the Eng as an open area, there is as a consequence also no room within the new allocation plan for shelter opportunities or larger storage spaces. It is not surprising therefore that the 16 public comments on the predesign requesting for the building of shelters or larger storage spaces were all neglected. This decision was justified by the conservative character of the new allocation plan, meaning that no changes were allowed, including no opportunities for further spatial developments. More importantly, it highlights how such "conservative" conceptualisations of the Eng, along with policy goals and the accompanying rules, decisively affect the materiality of the landscape (Coeterier, 1996).

Remarkably, the majority of public reactions concerning the Wageningse Eng were either rebutted or outright turned down for not fitting in the conservative character of the plan. Although the publication of the predesign was meant to encourage public participation and ensure a sense of transparency in the process - the cornerstone of spatial planning in the Netherlands - it appears as if only comments in line with the already-shaped predesign were incorporated into the following stages. This very fact thus possibly questions the notion of public participation in Dutch spatial planning and the ways in which, at the local level, this may be incorporated in practice into the decision-making process (see also Bulkens et al., 2014).

\subsection{The performative power of the "sight lines, sight areas and perspectives" Map}

Another example of how particular representations may have real effects on the material landscape is provided by the accounts provided by $\mathrm{Mr}$ and Mrs Evans, who have been longtime residents of the Wageningse Eng (see Fig. 3). In 2002, they participated in a project aimed at strengthening the "ecological structure" of the area by reintroducing "old" landscape elements, and they signed a 10-year contract with the commission of Landschapsbeheer Gelderland (2003) (Landscape Management Gelderland), which is responsible for the implementation of this project. Specifically, they sought to bring back a standard tree orchard on their property, conforming to the location of the orchard as captured by old aerial pictures of the area. Due to circumstances they postponed the project. When they decided to proceed with the original plan they went on to plant eight standard trees. However, reminiscent of the walnut tree incident mentioned at the beginning of the paper, a neighbour lodged an objection to this. Even with the presence of a signed contract with Landschapsbeheer Gelderland, the municipality declared the trees illegal. When the couple consulted the TAWE, they too came to learn that the trees were illegal for obstructing an "important" sight line (see Fig. 2). After a protracted debate, a compromise was reached with the TAWE, leading to the removal of two trees perceived as blocking the sight line. This particular dispute aside, what emerges here is again a discrepancy between historical conceptualisations of the landscape - including tree orchards, as shown by old aerial photos in the possession of $\mathrm{Mr}$ and Ms Evans - and other contemporary conceptualisations where the trees no longer have a place, as determined by the sight line rationale depicted by the TAWE. This is clearly reflected in the following quote by Mr and Mrs Evans on the turn of events:

Because the line of approach was to restore the old cultural elements in the landscape and the orchard also belonged to those as well as hedges. But of course it goes against the regulations of the municipality, because woody vegetation is not allowed. Thus, those trees, that is woody vegetation, but it is also an element in the cultural landscape. A standard tree, we especially selected an old apple strain. [...] And they [Landschapsbeheer Gelderland] say restore the cultural landscape but what moment of the past are you going to restore, right.

This raises the important question of which historical period should be taken as foundational when one speaks of "returning" to the landscape of the past, something that has clear implications for how the "right" landscape ought to be conceptualised and governed today. As our case shows, answers to this question potentially vary depending on who speaks. Even so, formal sets of representations, as concretised by the map as much as by the forthcoming allocation plan, do seem to take precedence when material changes to the actual landscape are involved, hence demonstrating the way in which formal plans are not only subjective but also instrumental in influencing real landscape production and practice, as these representations travel from the framing of policy to those who make the decisions on regulations and permits (Healey, 2002).

According to the rules of the current plan, a permit is needed when planting woody vegetation. The criteria for this to be granted are the proven necessity of this kind of vegetation for an efficient use of the land and whether the planted vegetation will substantially affect the "open character" of the landscape. In the case of the standard tree orchard discussed above, while it may be seen as respecting and reinforcing the parcelling structure of the presumedly (by some) "authentic" historical landscape, it does however go against the (also presumed) open character of the Eng, as defined by the allocation plan. What is important for the sake of our argument is indeed the more-than-representational role played 


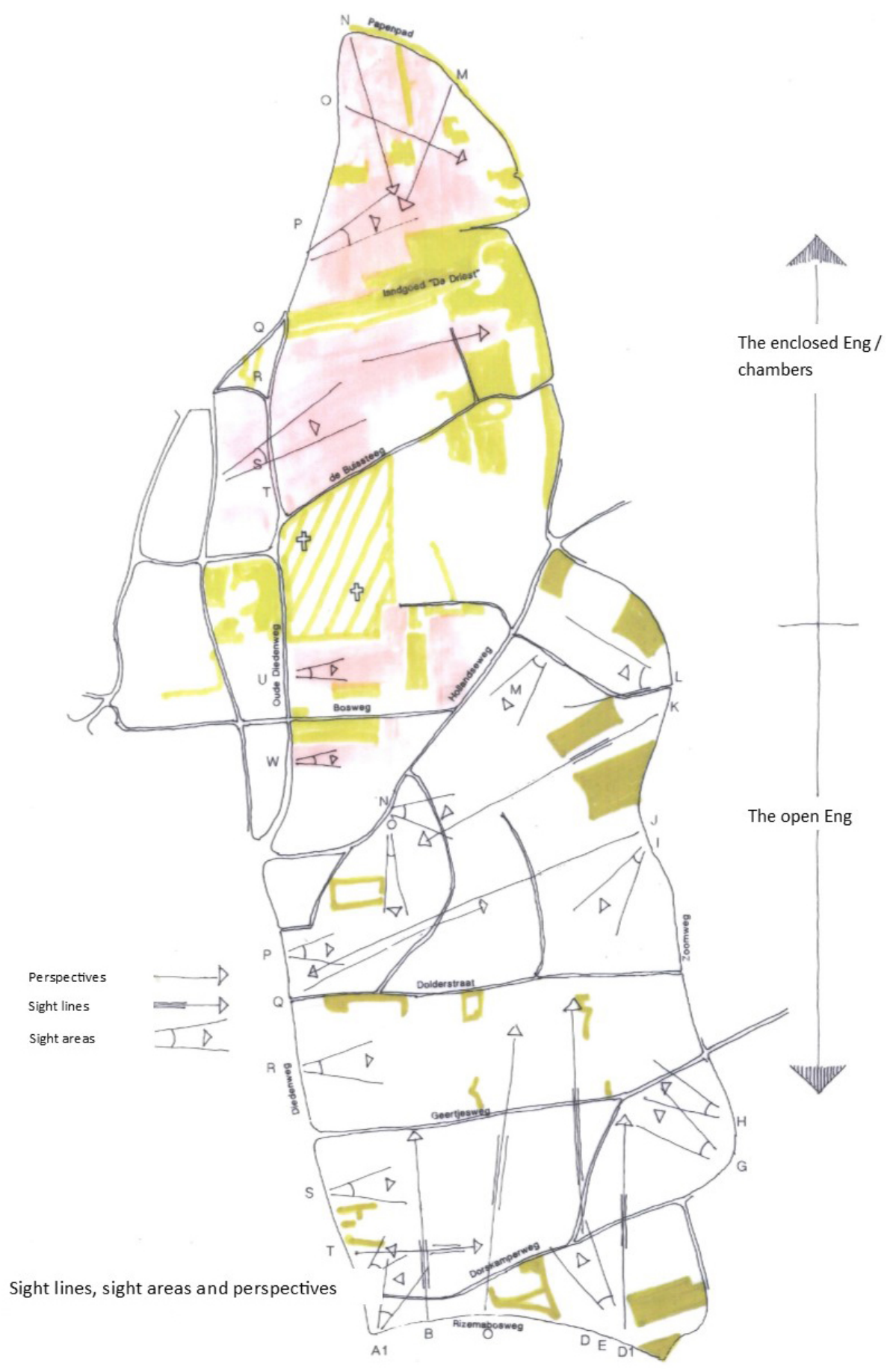

Figure 2. Sight lines, sight areas and perspectives map, source Territoriale Advies Commissie Wageningse Eng (2012, written permission translated by author's.).

by the term sight line (as stated in the TAWE's map) and how this led to the trees having been removed. This could perhaps be traced back to the specific type of landscape idyll in the Netherlands, which generally tends to emphasise scenic beauty and visual aesthetics over what it looked like before (see De Vries et al., 2012).
The discussion here therefore sheds light on the performative capacity and the impact of representational practices within spatial planning. Regardless of their basis in historical accuracy, and notwithstanding the fact that these are in fact contested on the ground, spatial metaphors used to describe the Wageningse Eng - as defined by the formal planning doc- 


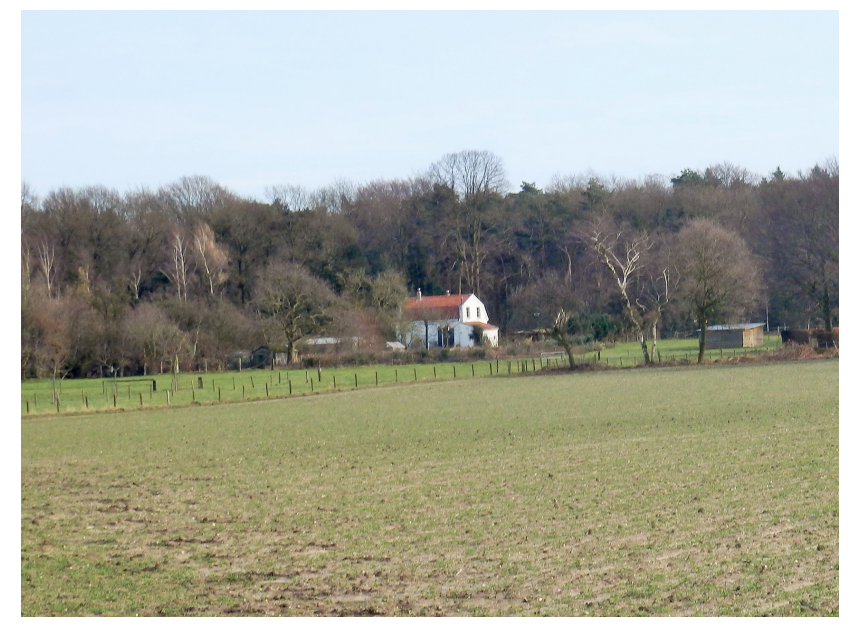

Figure 3. Property of Mr and Mrs Evans, photo by Maartje Bulkens.

uments and maps, such as openness, sight lines, unbroken area and "very striking views" - hold real implications beyond the representational; indeed, notwithstanding the historical foundations of these representations of the landscape, they have nevertheless led to actual material interventions in the landscape, such as the removal of trees. We would like to argue then that representations of the landscape, although contested, often remain important elements, or even 'acts', in shaping the materiality of the landscape: by being reiterated and reinforced in the planning process they gain the power to impact upon the landscapes and its residents and users. Landscape representations, in other words, maintain actual effects on the spaces where people live and with which they identify; or, at least, this is illustrative of the Wageningse Eng and possibly of many other Dutch cases.

This can indeed be interpreted as a plea for a more-thanrepresentational approach to the landscape within spatial planning, in which the landscape is as much part of the politics of representation, as it is of the daily spatial practice of the people gravitating around it. The performative power of the map in question, reflecting a representation of an ideal landscape made of sight lines and sight areas, is derived from the map gaining the status of a "regime of truth" (Harley, 1989; Woods, 1992, 2010), as Ms Turner's, member of the SWE, comments suggest:

That sight line map, I do think that is rather special, that map gains a status of truth, but that is located in a sight line, and then I think like well we can see five meters on the other side of the sight line and half a meter on the other side we also still can see.

Mr Hall, former member of the Association of Owners and Users of the Wageningse Eng, even went as far as to make an analogy with religion when discussing the sight lines, which he refers to as "a new article of faith"; their arbitrariness notwithstanding, they are still perceived as the way to go:
[Name of a party] takes it extremely far in "nothing is allowed", the Eng should remain open, and one building block of the fragile construction of the Wageningse Eng is absolutised, it is almost a religious something right.

The analogy with religion shows how this map is perceived by some as a sort of revealed "truth".

Nevertheless, like the open character of the Eng, the notion of a sight line is also criticised:

[Y]ou always get a situation with each sight line map you create that on paper there is a line.. That has a kind of inherent rigidity and arbitrariness, because you can draw the line of course a bit different. (Mr Hall, member of former Association of Owners and Users of the Wageningse Eng)

[The map] where they only talk about sight lines, when I saw that ten years ago for the first time, really the piece was absolutely full of arrows implicating that everything was a sight line, yes that is not a sight line. (Ms Wilkinson, member of the Advisory Committee)

The most recent version of the map consists of 29 different elements (ranging from sight areas to sight lines to perspectives). The map is a clear example of how, although arbitrary in nature, since those very lines could indeed be drawn differently, this representation of the landscape of the Eng creates the conditions for the actual implementation of future spatial developments in the area. As, again, Ms Evans puts it,

That [the sight lines] is really questionable, you see, you can debate about it. We agreed that the shed actually stands in a sight line. [...] We asked the opinion of a landscape architect, an independent person, and he said well those trees stand in the perfect place as they do now [...] because the trees of that neighbour over there those stand in the same line, and that reinforces the view. And in the past they also used to stand like this. But well for peace and quiet we decided to agree with the TAWE, like we want this to end, we just want it solved.

These quotes reflect on the arbitrary nature of the sight lines drawn by the TAWE. They also provide a concrete example of how powerful the sight line metaphors have become, through continuous repetition and reinforcement of these in the planning discourse concerning the Eng, having assumed the status of a sort of regime of truth. More than to argue about how the shaping of the landscape may be based on ideas about coherence and visual aesthetics in the Dutch context (see Couterier, 1996; De Vries et al., 2011), our contention is that such representations of visual aesthetics do hold real implications for the landscape and those involved 
with it. The powerful impact of the sight lines, as determined by the map (and the sight areas and perspectives, although these were not analysed in detail in this paper for lack of space), is something that critically problematises the actual participatory nature of the planning process, at least in the cases here described. The TAWE, also thanks to its map, not an official document but a potent more-than-representational tool indeed, has gained a dominant and powerful position in its role as advisory committee, while the map itself has achieved the status of a regime of truth over the definition (and the management) of the Wageningse Eng landscape.

\section{Discussion and conclusion}

The Wageningse Eng has proven to be a useful example of how spatial planning, even in a country characterised by a long tradition of participatory practice like the Netherlands, may be affected by the more-than-representational power of some representations, and not others. In addition, the case here studied reveals how, while the traditional focus on the representational aspects of landscape may rightly be criticised by the literature on non-representational theory in geography, at the same time representations remain powerful acts if employed in documents produced by institutions with the capacity of incorporating them as regimes of truth. This is precisely what we have tried to highlight in this paper by emphasising the role played by spatial metaphors like the ones adopted within the two key documents here taken into consideration.

All in all, this paper has shown how, within spatial planning practice - that is, the very "act of spatial planning" the representational may still play a decisive role in conceptualising and "naturalising" - as the realm of the taken for granted - what should and should not be allowed within the landscape. Representations captured in plans and maps in the case here studied have indeed become key and powerful sources in the definition of the natural and historical vocation of that landscape, for example by presenting it as "open to spectacular views".

Moreover, the representations of the (cultural) landscape of the Wageningse Eng - often based on certain "Dutch" ideals pertaining to landscape coherence, visual aesthetics and unity, through being repetitiously articulated - have gained a performative power in affecting not only the materiality of the landscape but also the practices of and within the landscape, even if this does not necessarily correspond to the historical nature and character of that specific landscape. Ad Maas' walnut tree was cut down for not fitting within the dominant institutional planning representation of the Wageningse Eng, like those produced and circulated by the municipality and the TAWE.

However, this paper has also demonstrated how, despite the hegemonic affordances of such representations of the landscape, they do not always go uncontested. Their histor- ical veracity aside, some of those who "practice" the landscape on a day-to-day basis, such as residents and visitors, have also argued that a representation of the Wageningse Eng as an open landscape with spectacular views makes the actual use of the Eng very difficult (if not impossible), implicitly accusing the politics of representation inherent to the incumbent planning of creating a deadening effect (Lorimer, 2005:83; Cadman, 2009:1) on the landscape as a place to live, where to keep horses, practice gardening, etc. A plea for a more-than-representational or post-representational approach to landscape planning practices thus allows for more attention to be paid to the actual practices of and in the Wageningse Eng landscape. This is particularly important in order to avoid "participation" becoming a mere pacifier term denoting a process of consensus building and cooperation, while actual decisions are made from the top down. If spatial planning is indeed aimed at being an inclusive participatory process of decision making, the more-than-representational role of some spatial metaphors like the one here analysed should be taken into full consideration, also for their implication for the actual practice of landscape.

Acknowledgements. This research is part of the strategic research program KBIV, "Sustainable spatial development of ecosystems, landscapes, seas and regions", funded by the Dutch Ministry of Economic Affairs and carried out by Wageningen University Research Centre. It was also funded by the Cultural Geography Chair Group at Wageningen University.

Edited by: B. Korf

Reviewed by: three anonymous referees

\section{References}

Anderson, B. and Harrison, P.: The promise of non-representational theories, in: Taking-place: non-representational theories and geography, edited by: Anderson, B. and Harrison, P., Ashgate, Farnham, United Kingdom, 1-36, 2010.

Boer, J.: Kafkaiaanse toestanden op de Wageningse Eng, De Veluwepost, 2012.

Bulkens, M., Minca, C., and Muzaini, H.: Storytelling as method in spatial planning, Eur. Plan. Stud., published online 8 August 2014.

Cadman, L.: Nonrepresentational Theory / Nonrepresentational Geographies, in: International Encyclopedia of Human Geography, edited by: Kitchin, R. and Thrift, N., Elsevier, Amsterdam, The Netherlands, 2009.

Coeterier, J. F.: Dominant Attitudes in the Perception and Evaluation of the Dutch Landscape, Landscape Urban Plan., 34, 27-44, 1996.

Cosgrove, D. and Daniels, S.: The Iconography of Landscape, Cambridge University Press, Cambridge, United Kingdom, 1988.

Cosgrove, D. and Jackson, P.: New Directions in Cultural Geography, Area, 19, 95-101, 1987.

Cresswell, T. and Verstraete, G.: Mobilizing Place, Placing Mobility, Rodopi Editions, Amsterdam, The Netherlands, 2003. 
Crouch, D.: Places Around Us, Leisure Stud., 19, 63-76, 2000.

Crouch, D.: Spacing, Performing, and Becoming, Environ. Plann. A, 35, 1945-1960, 2003.

De Vries, S., de Groot, M., and Boers, J.: Eyesores in Sight: Quantifying the Impact of Man-Made Elements on the Scenic Beauty of Dutch Landscapes, Landscape Urban Plan., 105, 118-127, 2012.

DeWRO: http://www.wetruimtelijkeordening.net/page.php?3, last access: 30 May 2013.

Dewsbury, J.-D.: Performativity and the Event, Environ. Plann. D, 18, 473-496, 2000.

Dewsbury, J. D., Harrison, Rose, M., and Wylie, J.: Enacting geographies, Geoforum, 33, 437-440, 2002.

Duncan, J. and Ley, D.: Introduction: Representing the place of culture, in: Place/Culture/Representation, edited by: Duncan, J. and Ley, D., Routledge, London, United Kingdom, 1-21, 1993.

Evers, D.: Reflections on territorial cohesion and European spatial planning, Tijdschr. Econ. Soc. Ge., 99, 303-315, 2008.

Gemeente Goes: http://www.goes.nl/bestemmingsplannen/ procedure-bestemmingsplan_3760/, last access: 2 July 2012.

Gemeente Wageningen: Reactienota Voorontwerpbestemmingsplan Buitengebied, Gemeente Wageningen, Wageningen, The Netherlands, 2012a.

Gemeente Wageningen: Voorontwerp Bestemmingsplan Buitengebied, Gemeente Wageningen, Wageningen, The Netherlands, 2012b.

Gemeente Wageningen: http://www.wageningen.nl/Ontdek_ Wageningen/Feiten_en_cijfers/Algemene_feiten_en_cijfers, last access: 6 May 2012c.

Gemeente Wageningen: Ontwerp Bestemmingsplan Buitengebied, Gemeente Wageningen, Wageningen, The Netherlands, 2013.

Graham, S. and Healey, P.: Relational Concepts of Space and Place, Eur. Plan. Stud., 7, 623-646, 1999.

Habiforum: System Innovation urban and regional land use and area development. Habiforum. Gouda, The Netherlands, 2003.

Hagens, J. E.: The performance of landscape concepts in spatial planning, Ph.D. thesis, Wageningen University, Wageningen, The Netherlands, 180 pp., 2010.

Harley, J. B.: Deconstructing the Map, Cartographica, 26, 1-20, 1989.

Harrison, P.: Making sense: embodiment and the sensibilities of the everyday, Environ. Plann. D, 18, 497-517, 2000.

Healey, P.: On Creating the "City" as a Collective Resource, Urban. Stud., 39, 1777-1792, 2002.

Healey, P.: The Treatment of Space and Place in the New Strategic Spatial Planning in Europe, Int. J. Urban. Regional., 28, 45-67, 2004.

Hillier, J.: Stretching beyond the horizon, Ashgate Publishing ltd, Aldershot, United Kingdom, 2007.

Ingold, T.: The Perception of the Environment, Routledge, London, United Kingdom, 2000.

Jovchelovitch, S. and Bauer, M. W.: http://eprints.lse.ac.uk/2633 (Narrative interviewing) (last access: 19 May 2014), 2000.

Landschapsbeheer Gelderland: http://www. landschapsbeheergelderland.nl/over-ons/over-ons, last access: 27 September 2013.
Lorimer, H.: Telling small stories, T. I. Brit. Geogr., 28, 197-217, 2003.

Lorimer, H.: Cultural geography: the busyness of being "more-thanrepresentational”, Prog. Hum. Geogr., 29, 83-94, 2005.

Lorimer, H.: Herding memories of humans and animals. Environ. Plann. D, 24, 497-518, 2006.

McHugh, K.: Movement, Memory, Landscape, GeoJournal, 74, 209-218, 2009.

Minca, C.: The tourist landscape paradox, Soc. Cult. Geogr., 8, 433453, 2007a.

Minca, C.: Humboldt's compromise, or the forgotten geographies of landscape, Prog. Hum. Geogr., 31, 179-193, $2007 \mathrm{~b}$.

Mitchell, D.: Cultural Geography, Blackwell, Oxford, United Kingdom, 2000.

Mitchell, D.: The lure of the local, Prog. Hum. Geogr., 25, 269-281, 2001.

Mitchell, D.: Cultural landscapes: the dialectical landscape - recent landscape research in human geography, Prog. Hum. Geogr., 26, 381-389, 2002.

Mooi Wageningen: http://www.mooiwageningen.nl/wat-wij-doen, last access: 30 August 2012.

Needham, B.: Dutch Land Use Planning, Sdu Uitgevers bv, Den Haag, the Netherlands, 2007.

Oakes, T. S. and Price, L.: The Cultural Geography Reader, Routledge, London, United Kingdom, 2008.

Pløger, J.: In Search of Urban Vitalis, Space and Culture, 9, 382399, 2006.

Renes, H.: De Wageningse Eng, Eemvallei, 2, 61-80, 1993.

Staatscourant: https://zoek.officielebekendmakingen.nl/ stcrt-2013-4953.html, last access: 28 February 2013.

Stichting Wageningse Eng: http://wageningseeng.nl/wie-zijn-wij/ missie-en-visie/, last access: 2 May 2012.

TAWE (Territorial Advisory Committee Wageningse Eng): Zienswijze op het voorontwerp bestemmingsplan buitengebied gemeente Wageningen, TAWE, Wageningen, 2012.

Thrift, N.: Spatial Formations, Sage Publications, London, United Kingdom, 1996.

Thrift, N.: Non-representational theory, in: The Dictionary of Human Geography, Blackwell, Oxford, United Kingdom, 556-689, 2000.

Thrift, N.: Non-Representational Theory, Routledge, London, United Kingdom, 2007.

Van Assche, K.: Signs in time, Ph.D. thesis, Wageningen University, Wageningen, The Netherlands, 343 pp., 2004.

Van der Valk, A.: The Dutch planning experience, Landscape Urban Plan., 58, 201-210, 2002.

Woods, D.: The Power of Maps, The Guilford Press, New York, United States, 1992.

Woods, D.: Rethinking the Power of Maps, The Guilford Press, New York, United States, 2010.

Wylie, J.: A single day's walking, T. I. Brit. Geogr., 30, 234-247, 2005.

Wylie, J.: Landscape, Routledge, London, United Kingdom, 2007. 